\title{
Pemetaan Kemiskinan Melalui Pendekatan Geographically Weighted Lasso
}

\author{
Rita Herawaty Br Bangun ${ }^{a, *}, \&$ Aida Meimela ${ }^{b}$ \\ ${ }^{a}$ BPS Provinsi Sumatera Utara \\ ${ }^{b}$ Pascasarjana Statistik Terapan Universitas Padjajaran
}

\begin{abstract}
The purpose of this study is to analyze poverty according to regional variations with spatial approach through the application of Geographically Weighted Lasso (GWL) method. The study draws the case of North Sumatera, a province with high poverty-level in Indonesia. This study uses secondary data derived from the published book and BPS-Statistics Indonesia. The GWL method can overcome the local multicollinearity and heterogeneity in spatial data. The results show that 85.93 percent of poverty in North Sumatera could be explained by all predictor variables. The significant variables are the percentage of households with a floor area below $8 \mathrm{~m}^{2}$, a half-unemployment rate, and a percentage of informal workers. Poverty modeling with the GWL method can increase the accuracy of the parameter estimation so that the poverty alleviation programs can be more effective if adjusted to the characteristics of each region.
\end{abstract}

Keywords: geographically weighted lasso; heterogeneity; multicollinearity; poverty; spatial

\begin{abstract}
Abstrak
Penelitian ini bertujuan menganalisis kemiskinan menurut variasi wilayah dengan pendekatan spasial melalui penerapan metode Geographically Weighted Lasso (GWL). Studi kasus yang diambil adalah Sumatera Utara, salah satu provinsi dengan tingkat kemiskinan tertinggi di Indonesia. Data penelitian bersifat sekunder yang berasal dari publikasi dan laman BPS. Hasil penelitian menunjukkan metode GWL mampu mengatasi multikolinieritas lokal dan heterogenitas data spasial. Sebesar 85,93 persen kemiskinan di Sumatera Utara dapat dijelaskan oleh seluruh variabel prediktor. Variabel yang signifikan adalah persentase rumah tangga dengan luas lantai kurang dari $8 \mathrm{~m}^{2}$, tingkat setengah pengangguran, dan persentase pekerja informal. Pemodelan kemiskinan dengan metode GWL mampu meningkatkan ketepatan estimasi parameter sehingga program pengentasan kemiskinan di Sumatera Utara akan lebih efektif jika disesuaikan dengan karateristik masing-masing daerah.
\end{abstract}

Kata Kunci: geographically weighted lasso; heterogenitas; kemiskinan; multikolinieritas; spasial

JEL Classification: C53; I32; R12

${ }^{*}$ Alamat Korespondensi Penulis: Jln. Asrama No. 179 Medan 20123. E-mail: rita.bangun@bps.go.id. 


\section{Pendahuluan}

Pandemi Covid-19 telah menyebabkan krisis sosial dan ekonomi pada sebagian besar wilayah dunia, tidak terkecuali Indonesia dan semua provinsi, termasuk di Sumatera Utara. Dampak tersebut menyentuh sampai ke lapisan masyarakat bawah, terutama kelompok masyarakat miskin dan rentan miskin (BPS Provinsi Sumatera Utara, 2020a). Angka kemiskinan di Sumatera Utara naik sebesar 0,12 poin dari 8,63 persen pada September 2019 menjadi 8,75 persen pada Maret 2020 (BPS Provinsi Sumatera Utara, 2020b). Hal ini menjadi salah satu indikator bahwa Covid-19 berdampak pada tingkat kemiskinan di Provinsi Sumatera Utara. Lebih lanjut, indeks kedalaman kemiskinan dan indeks keparahan juga mengalami kenaikan dibandingkan kondisi pada September 2019. Hal ini mengindikasikan bahwa terjadi penurunan rata-rata pengeluaran penduduk miskin dan makin tingginya ketimpangan pengeluaran antar penduduk miskin (Tambun \& Herawaty, 2018).

Berdasarkan konsep yang dikembangkan oleh BPS (2019), kemiskinan didefenisikan sebagai ketidakmampuan manusia untuk memenuhi kebutuhan dasar yang meliputi kebutuhan makanan dan bukan makanan yang diukur dari pendekatan pengeluaran. Untuk mengatasi masalah kemiskinan perlu dilakukan usaha dalam rangka pengentasan kemiskinan. Pengentasan kemiskinan merupakan salah satu tujuan pembangunan berkelanjutan (Suistainable Development Goals) yang telah disepakati oleh negara-negara di dunia. Pentingnya melakukan pengentasan kemiskinan adalah untuk peningkatan kualitas hidup manusia dalam rangka perwujudan tujuan pembangunan berkelanjutan (Bangun, 2020; Dariwardani, 2014; Puspita, 2015).

Faktor-faktor penyebab kemiskinan pada suatu wilayah tidak dapat dilakukan dengan metode pendekatan analisis yang sama karena setiap wilayah memiliki karakteristik yang beragam. Karakteristik khas wilayah menjadi hal yang sangat penting untuk dijadikan sebagai faktor dalam pendekatan analisis kemiskinan. Salah satu pendekatan yang memungkinkan untuk menganalisis suatu wilayah dalam hal kemiskinan melalui pendekatan spasial. Pendekatan spasial digunakan untuk mengidentifikasi pengaruh faktor geografis suatu wilayah. Perbedaan letak geografis akan berpengaruh terhadap potensi yang dimiliki atau digunakan oleh suatu daerah. Oleh karena itu diperlukan suatu metode pemodelan statistik yang memperhatikan letak geografis atau faktor lokasi pengamatan. Maggri \& Ispriyanti (2013) menjelaskan bahwa penambahan efek spasial mampu menjelaskan dan menentukan model kemiskinan yang lebih baik.

Penelitian kemiskinan dengan pendekatan spasial telah banyak dilakukan antara lain penelitian tentang pemodelan penduduk miskin di Jawa Timur dengan metode Geographically Weighted Regression (Damayanti \& Ratnasari, 2013), kemiskinan di Jawa Tengah dengan metode Geographically Weighted Regression (Agustina et al., 2015), dan penelitian kemiskinan di Jawa Tengah dengan metode Geographically Weighted Logistic Regression (Wulandari, 2018). Kusuma \& 
Wulansari (2020) menjelaskan bahwa kemiskinan bersifat multidimensi yang melibatkan banyak variabel independen sehingga sering terjadi pelanggaran asumsi non multikolineritas. Geographically Weighted Lasso (GWL) merupakan salah satu metode yang digunakan untuk mengatasi keragaman wilayah yang disebabkan oleh letak dan kondisi yang berbeda antar wilayah serta munculnya multikolinieritas lokal (Wang \& Zuo, 2020). Dengan metode ini setiap wilayah akan memiliki model regresi yang berbeda-beda sesuai dengan karateristiknya masing-masing. Penelitian sebelumnya menunjukkan bahwa error estimasi model GWL lebih kecil dibanding model GWR (Wheeler, 2009). Setiyorini et al. (2017) dalam penelitiannya tentang kemiskinan di Pulau Jawa menyimpulkan bahwa metode GWL lebih baik dibanding dengan metode GWR pada data spasial yang mengandung multikonieritas.

Penelitian tentang pemodelan kemiskinan dengan pendekatan spasial di Provinsi Sumatera Utara belum pernah dilakukan sebelumnya. Untuk itu penelitian ini menjadi menarik untuk dilakukan. Tujuan dari penelitian ini adalah untuk menganalisis kemiskinan menurut variasi wilayah dengan pendekatan spasial melalui penerapan metode Geographically Weighted Lasso.

\section{Metode Penelitian}

Penelitian ini menggunakan data sekunder dari Badan Pusat Statistik (BPS) Provinsi Sumatera Utara. Data diperoleh dari buku publikasi dan informasi dari laman BPS. Data yang digunakan dalam penelitian ini merupakan data kerat lintang yang meliputi 33 kabupaten/kota di Provinsi Sumatera Utara pada tahun 2019. Variabel respon dalam penelitian ini adalah persentase penduduk miskin, sedangkan variabel penjelas terdiri dari persentase rumah tangga dengan luas lantai $<8 \mathrm{~m}^{2}$ per kapita, persentase penduduk yang menggunakan listrik PLN, persentase penduduk yang mengalami keluhan kesehatan selama sebulan terakhir, tingkat setengah pengangguran, persentase pekerja informal, indeks pembangunan manusia (IPM), dan tingkat partisipasi angkatan kerja (TPAK). Pemilihan variabel respon mengacu pada beberapa penelitian terdahulu seperti Saputro \& Utomo (2010) yang menggunakan variabel karakteristik rumah tangga dan pekerjaan untuk memodelkan kemiskinan di lima belas provinsi di Indonesia dan Setiyorini et al. (2017) menggunakan variabel karakteristik rumah tangga, IPM, dan TPAK untuk melihat kemiskinan di Pulau Jawa.

Metode penelitian ini menggunakan analisis regresi spasial. Analisis regresi spasial dilakukan jika data memenuhi efek spasial, yaitu adanya dependensi dan keragaman spasial (Anselin, 1988). Identifikasi adanya dependensi spasial jika suatu observasi memiliki pengaruh terhadap observasi lain yang lokasinya berdekatan. Pengukuran dependensi spasial menggunakan uji Moran I. Identifikasi adanya keragaman spasial jika terdapat perbedaan karateristik antar wilayah satu dengan yang lainnya (Fotheringham et al., 2002). Pengukuran keragaman spasial menggunakan uji Breush Pagan (Anselin, 1988). Analisis dan pemodelan statistik menggunakan perangkat lunak tidak berbayar $R$-Studio version 3.4.2. 


\subsection{Multikolinieritas Lokal}

Multikolinieritas merupakan permasalahan yang sering muncul pada data spasial. Ada dua jenis kasus multikolinieritas y,aitu multikolinieritas hampir sempurna (near dependency) dan multikolinieritas sempurna (exact multicollinearity). Multikolinieritas berefek pada nilai koefisien regresi yang tidak dapat ditentukan dan memiliki standar eror yang tak terhingga. Sementara itu multikolinieritas hampir sempurna menyebabkan varians dan standar eror estimasi koefisien regresi besar (Gujarati \& Porter, 2009). Salah satu cara untuk mendeteksi adanya multikolinieritas lokal adalah dengan menghitung nilai VIF yang dirumuskan sebagai berikut (Wheeler, 2007):

$$
\operatorname{VIF}_{k}(i)=\frac{1}{1-R_{k}^{2}(i)}
$$

dimana $R_{k}^{2}(i)$ adalah koefisien determinasi ketika $x_{k}$ diregressikan dengan variabel penjelas lainnya untuk tiap lokasi ke-i. Nilai $V I F>10$ mengindikasikan terjadinya multikolinieritas lokal.

\subsection{Geographically Weighted Lasso (GWL)}

Geographically Weighted Lasso (GWL) adalah metode analisis spasial yang mampu mengatasi adanya multikolinieritas lokal. GWL merupakan model konstruksi antara geographically weighted regression (GWR) dengan least absolute shrinkage and selection operator (LASSO) (Yuliana \& Saputro, 2017). Metode ini juga sekaligus menyeleksi variabel yang tidak signifikan dengan cara menyusutkan nilai koefisien regresi sampai ke nol dengan pendekatan Lasso. Formula dalam metode ini dirumuskan sebagai berikut (Wheeler, 2009):

$\hat{\beta}_{G W L}\left(u_{i}, v_{i}\right)=\arg _{\beta} \min \left\{\sum_{i=1}^{n}\left(y_{i}-\beta_{0}\left(u_{i}, v_{i}\right)-\sum_{k=1}^{p} x_{i k} \beta_{k}\left(u_{i}, v_{i}\right)\right)^{2}+\lambda \sum_{k=1}^{p}\left|\beta_{k}\left(u_{i}, v_{i}\right)\right|\right\}$

dengan syarat $\sum_{k=1}^{p}\left|\beta_{k}\left(u_{i}, v_{i}\right)\right| \leq s_{i}$. Dimana $s$ adalah nilai parameter penyusutan dan $\lambda$ bandwidth optimum. Sebuah algoritma yang mampu menyelesaikan solusi lasso, yakni dengan algoritma LARS (least angle regression) (Efron et al., 2004). Model GWL tergantung pada pembobot yang digunakan. Fungsi pembobot yang digunakan dalam penelitian ini adalah Fixed Exponential Kernel yang dituliskan sebagai berikut (Fotheringham et al., 2002):

$$
w_{j}\left(u_{i}, v_{i}\right)=\exp \left(\frac{d_{i j}}{h}\right)
$$

dimana $d_{i j}=\sqrt{\left(u_{i}-u_{j}\right)^{2}+\left(v_{i}-v_{j}\right)^{2}}$ adalah jarak Euclidean lokasi $\left(u_{i}, v_{i}\right)$ dengan lokasi $\left(u_{j}, v_{j}\right)$ dan $h$ adalah bandwidth optimum yang fixed atau yang sama di semua lokasi. Pemilihan bandwidth optimum juga memengaruhi ketepatan hasil estimasi 
parameter. Salah satu metode yang dapat digunakan adalah Cross Validation (CV) yang dituliskan sebagai berikut:

$$
C V(h)=\sum_{i=1}^{n}\left[y_{i}-\hat{y}_{\neq i}(h)\right]^{2}
$$

dimana $\hat{y}_{\neq i}(h)$ adalah nilai taksiran untuk $y_{i}$ dengan bandwidth $h$. Pemilihan bandwith optimum diperoleh dari proses iterasi yang menghasilkan bandwith paling kecil (Fotheringham et al., 2002).

\section{Hasil dan Pembahasan}

\subsection{Profil Kemiskinan di Sumatera Utara}

Sumatera Utara merupakan salah satu provinsi di Indonesia dengan tingkat kemiskinan yang tinggi. Jumlah penduduk miskin di Sumatera Utara sebesar 1,28 juta jiwa dengan persentase penduduk miskin sebesar 8,33 persen pada tahun 2019 (BPS Provinsi Sumatera Utara, 2020c). Sebaran persentase penduduk miskin di Provinsi Sumatera Utara pada tahun 2019 cukup bervariasi antar kabupaten/kota. Persebaran persentase penduduk miskin menurut kabupaten/kota disajikan pada Gambar 1.

Informasi tentang kluster persentase penduduk miskin merupakan salah satu bahan yang penting dalam penyusunan kebijakan program pengentasan kemiskinan (Wulandari, 2018). Sebaran persentase penduduk miskin di Sumatera Utara cukup beragam dengan rentang antara 3,89 persen sampai 25,51 persen. Wilayah dengan persentase penduduk miskin tertinggi adalah kabupaten/kota yang berada di Kepulauan Nias dengan persentase penduduk miskin di atas 15 persen. Persentase penduduk miskin di Kabupaten Nias Barat sebesar 25,51 persen, Kabupaten Nias Utara sebesar 24,99 persen, Kabupaten Nias Selatan sebesar 16,45 persen, Kabupaten Nias sebesar 15,94 persen dan Kota Gunungsitoli sebesar 15,94 persen (BPS Provinsi Sumatera Utara, 2020c). Daerah yang merupakan kawasan penyangga ibukota provinsi memiliki persentase penduduk miskin yang rendah. Persentase penduduk miskin di Kabupaten Deli Serdang sebesar 3,89 persen, Kota Binjai sebesar 5,66 persen, dan Kota Medan sebesar 8,08 persen (BPS Provinsi Sumatera Utara, 2020c).

Tingginya tingkat kemiskinan di Pulau Nias menjadi perhatian serius bagi pemerintah daerah Provinsi Sumatera Utara. Penguatan kelembagaan serta pembangunan infrastruktur pendidikan dan kesehatan merupakan salah satu upaya untuk pengentasan kemiskinan di Pulau Nias.

Deskripsi masing-masing variabel penelitian dapat dilihat pada Tabel 1. Persentase pekerja informal memiliki keragaman yang tinggi antar wilayah. Hal ini ditunjukkan dari nilai standar deviasi yang paling tinggi dibandingkan dengan variabel lainnya. Keragaman pekerja informal antar wilayah dapat dipengaruhi oleh aktivitas ekonomi dan tingkat upah yang berbeda antar wilayah (Sutopo \& 


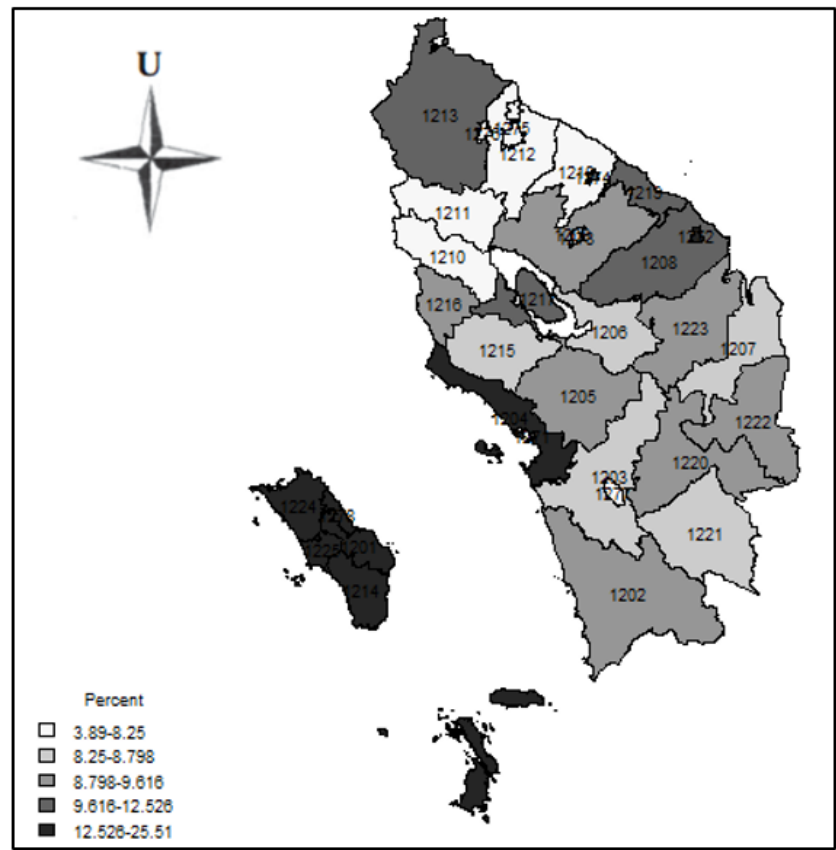

Gambar 1: Persebaran Persentase Penduduk Miskin di Sumatera Utara Tahun 2019

Ardianti, 2014).

Tabel 1: Deskripsi Variabel Penelitian

\begin{tabular}{|c|c|c|c|c|}
\hline Variabel & Minimum & Maksimum & $\begin{array}{l}\text { Rata- } \\
\text { Rata }\end{array}$ & $\begin{array}{l}\text { Standar } \\
\text { Deviasi }\end{array}$ \\
\hline Persentase penduduk miskin & 3,89 & 25,51 & 10,82 & 4,66 \\
\hline $\begin{array}{l}\text { Persentase rumah tangga dengan luas lantai }<8 \mathrm{~m}^{2} \text { per } \\
\text { kapita }\end{array}$ & 5,37 & 34,88 & 16,44 & 8,09 \\
\hline Persentase penduduk yang menggunakan listrik PLN & 66,68 & 100,00 & 94,88 & 8,26 \\
\hline $\begin{array}{l}\text { Persentase penduduk yang mengalami keluhan kese- } \\
\text { hatan selama sebulan terakhir }\end{array}$ & 8,31 & 19,57 & 12,94 & 3,26 \\
\hline Tingkat setengah pengangguran & 2,93 & 21,84 & 9,22 & 4,18 \\
\hline Persentase pekerja informal & 32,20 & 86,38 & 62,25 & 17,20 \\
\hline IPM & 61,14 & 80,97 & 70,57 & 4,67 \\
\hline TPAK & 62,39 & 88,55 & 73,71 & 7,63 \\
\hline
\end{tabular}

Persentase penduduk yang mengalami keluhan kesehatan memiliki standar deviasi terkecil dibandingkan dengan variabel lainnya. Hal ini menggambarkan bahwa penduduk yang memiliki keluhan kesehatan cukup merata antar wilayah di Sumatera Utara. Aspek kesehatan berkaitan dengan kemiskinan. Sisca HS et al. (2013) menjelaskan bahwa peningkatan derajat kesehatan akan menurun- 
kan tingkat kemiskinan karena individu yang tingkat kesehatannya lebih baik berpeluang untuk memperoleh pendapatan lebih tinggi.

\subsection{Pengujian Dependensi dan Heterogenitas Spasial}

Tahap awal dalam melakukan pemodelan GWL adalah melakukan pengecekan dependensi dan heterogenitas spasial. Hasil pengujian dengan Moran's I menunjukkan bahwa terdapat dependensi spasial pada variabel respon. Hasil uji indeks Moran diperoleh sebesar 0,68 dengan nilai signifikansi yang sangat kecil dibawah 0,05. Septiyanto \& Tusianti (2020) menjelaskan bahwa nilai Moran's I positif menunjukkan adanya autokorelasi spasial dengan pola pengelompokan di suatu daerah. Dapat disimpulkan bahwa kemiskinan suatu wilayah berpengaruh terhadap wilayah lain yang berdekatan.

Hasil pengujian heterogenitas spasial dengan uji Breush-Pagan menunjukkan adanya keragaman spasial pada setiap wilayah di Sumatera Utara. Nilai signifikansi sebesar 0,03 sehingga dapat disimpulkan bahwa pada taraf nyata 5 persen pada model terdapat keragaman spasial yang mengindikasikan setiap wilayah di Sumatera Utara memiliki karateristik yang berbeda-beda. Hasil pengujian dependensi dan heterogenitas spasial menunjukkan bahwa pemodelan regresi global untuk kemiskinan di Sumatera Utara tidak dapat dilakukan karena variabel mengandung efek spasial sehingga diperlukan pemodelan yang bersifat lokal agar dapat menjelaskan efek variasi spasial tersebut.

Tabel 2: Hasil Uji Indeks Moran dan Breusch-Pagan

\begin{tabular}{lcc}
\hline \hline Uji & Statistik Uji & $p$-value \\
\hline Indeks Moran & 0,68 & 0,00000 \\
Breusch Pagan & 15,24 & 0,03 \\
\hline
\end{tabular}

\subsection{Geographical Weighted Regression (GWR)}

Pemodelan Geographical Weighted Regression (GWR) digunakan untuk mengatasi keragaman spasial pada wilayah pengamatan (Maggri \& Ispriyanti, 2013). Hal pertama yang dilakukan dalam pemodelan GWR adalah menentukan matriks pembobot menggunakan bandwidth optimum. Nilai bandwidth optimum diperoleh sebesar 0,47. Nilai ini menjelaskan bahwa wilayah yang berada di atas 0,47 derajat dianggap sudah tidak memengaruhi kemiskinan di lokasi pengamatan tersebut.

Tabel 3 mendeskripsikan bahwa variabel penjelas yang memiliki hubungan negatif dengan persentase penduduk miskin adalah IPM, sedangkan variabel yang lain mempunyai hubungan yang bervariasi antara positif dan negatif dengan variabel persentase penduduk miskin di beberapa wilayah lokasi pengamatan.

Tahap selanjutnya untuk mengetahui adanya multikolineritas lokal pada model GWR dapat dilihat dari nilai VIF lokal. Nilai VIF pada Tabel 4 menunjukkan 
Tabel 3: Estimasi Parameter Model GWR

\begin{tabular}{lll}
\hline \hline Parameter & Minimum & Maksimum \\
\hline Intersep & 30,99 & 130,59 \\
Persentase rumah tangga dengan luas lantai $<8 \mathrm{~m}^{2}$ per kapita & $-0,39$ & 0,35 \\
Persentase penduduk yang menggunakan listrik PLN & $-0,11$ & 0,18 \\
Persentase penduduk yang mengalami keluhan kesehatan selama sebulan & $-0,29$ & 0,56 \\
terakhir & & \\
Tingkat setengah pengangguran & $-0,51$ & 0,40 \\
Persentase pekerja informal & $-0,33$ & 0,23 \\
IPM & $-1,85$ & $-0,23$ \\
TPAK & $-0,53$ & 0,32 \\
\hline
\end{tabular}

bahwa terdapat mulikolineritas lokal pada peubah penjelas yang lebih besar dari 10. Nilai VIF menunjukkan seberapa besar varians suatu variabel akan meningkat jika variabel tersebut memiliki hubungan dengan variabel lain. Variabel yang mengandung multikolinieritas lokal yaitu persentase penduduk yang menggunakan listrik PLN, tingkat setengah pengangguran, persentase pekerja informal, IPM, dan TPAK.

Variabel dengan jumlah multikolinieritas lokal terbanyak adalah persentase pekerja informal yakni 12 kabupaten/kota. Pekerja informal di Kabupaten Nias Barat memiliki nilai VIF terbesar diantara yang lain. Hal ini berarti varians pekerja informal di Kabupaten Nias Barat akan meningkat sebesar 45,95 disebabkan adanya korelasi variabel tersebut dengan variabel lain.

Tabel 4: Nilai VIF Lokal

\begin{tabular}{lllll}
\hline \hline Variabel & Minimum & $\begin{array}{r}\text { Maksimum Rata- } \\
\text { Rata }\end{array}$ & $\begin{array}{l}\text { Jumlah Kab/Kota de- } \\
\text { ngan Nilai VIF }>10\end{array}$ \\
\hline $\begin{array}{l}\text { Persentase rumah tangga dengan luas lan- } \\
\text { tai }<8 \mathrm{~m}^{2} \text { per kapita }\end{array}$ & 1,19 & 5,76 & 2,09 & - \\
$\begin{array}{l}\text { Persentase penduduk yang menggunakan } \\
\text { listrik PLN }\end{array}$ & 1,39 & 39,97 & 7,23 & 4 \\
$\begin{array}{l}\text { Persentase penduduk yang mengalami ke- } \\
\text { luhan kesehatan selama sebulan terakhir }\end{array}$ & 1,13 & 8,48 & 2,71 & - \\
Tingkat setengah pengangguran & 2,51 & 32,02 & 6,86 & 5 \\
Persentase pekerja informal & 4,56 & 22,43 & 11,10 & 12 \\
IPM & 1,55 & 45,95 & 9,37 & 6 \\
TPAK & 3,06 & 11,96 & 6,22 & 3 \\
\hline
\end{tabular}

Terjadinya multikolinieritas pada model GWR dapat menyebabkan hasil dugaan parameter memiliki ragam yang besar sehingga mengakibatkan kesalahan dalam interpretasi model (Yulita et al., 2015). Untuk mengatasi hal ini maka digunakan metode Geographically Weighted Lasso (GWL).

Pada pemodelan GWL, masing-masing lokasi pengamatan memiliki model yang berbeda-beda. Berdasarkan konsep Lasso beberapa koefisien pada model GWL menyusut hingga ke nol di beberapa wilayah penelitian yang otomatis menjadikan variabel bersesuaian tersebut tidak signifikan terhadap model. Pe- 
modelan dengan GWL juga terjadi proses seleksi variabel. Hasil pemodelan menggunakan metode GWL dengan semua variabel penjelas memiliki pengaruh yang bervariasi antara negatif dan positif di beberapa wilayah pengamatan. Nilai 0,00 menunjukkan bahwa variabel yang bersangkutan tidak signifikan pada lokasi pengamatan tertentu.

Hasil estimasi parameter model GWL dapat dilihat pada Tabel 5. Variabel yang memiliki hubungan negatif dengan variabel respon pada model GWL adalah persentase penduduk yang menggunakan listrik PLN, IPM dan TPAK di beberapa lokasi pengamatan sedangkan variabel yang lain mempunyai hubungan yang bervariasi antara negatif dan positif terhadap variabel respons.

Tabel 5: Estimasi Parameter GWL

\begin{tabular}{|c|c|c|c|}
\hline Estimasi Parameter & Minimum & Maksimum & Rata-rata \\
\hline Intersep & 0 & 149,89 & 28,24 \\
\hline $\begin{array}{l}\text { Persentase rumah tangga dengan luas lantai }<8 \mathrm{~m}^{2} \text { per } \\
\text { kapita }\end{array}$ & $-0,57$ & 0,39 & 0,09 \\
\hline Persentase penduduk yang menggunakan listrik PLN & $-0,17$ & 0,19 & $-0,01$ \\
\hline $\begin{array}{l}\text { Persentase penduduk yang mengalami keluhan kesehat- } \\
\text { an selama sebulan terakhir }\end{array}$ & $-0,35$ & 0,36 & 0,01 \\
\hline Tingkat setengah pengangguran & $-0,50$ & 0,79 & 0,04 \\
\hline Persentase pekerja informal & $-0,49$ & 0,24 & 0 \\
\hline IPM & $-1,71$ & 0 & $-0,24$ \\
\hline TPAK & $-0,60$ & 0,43 & $-0,04$ \\
\hline
\end{tabular}

Pengelompokan kabupaten/kota berdasarkan model kombinasi penyebab kemiskinan dapat dilihat pada Tabel 7. Berdasarkan hasil pengolahan data sebagian besar variabel mempengaruhi kemiskinan di hampir semua wilayah kabupaten/kota di Sumatera Utara. Variabel ini berkaitan dengan kondisi masingmasing wilayah kabupaten/kota. Variabel yang signifikan di banyak wilayah kabupaten/kota untuk memodelkan tingkat kemiskinan di Sumatera Utara adalah persentase rumah tangga dengan luas lantai di bawah $8 \mathrm{~m}^{2}$, tingkat setengah pengangguran dan persentase pekerja informal. Yandri \& Juanda (2018) menjelaskan bahwa kemiskinan erat kaitannya dengan kerawanan tempat tinggal dan masalah sanitasi lingkungan. Dinamika sektor pekerjaan juga berpengaruh terhadap kemiskinan. Pemanfaatan angkatan kerja pada usia produktif dan berfokus terhadap sektor informal menjadi salah satu cara dalam penanggulangan kemiskinan (Basorudin et al., 2019; Taufiq, 2017).

Hasil pengolahan data menunjukkan bahwa karakteristik rumah tangga dan ketenagakerjaan merupakan variabel yang berpengaruh penting dalam kemiskinan di wilayah kabupaten/kota di Provinsi Sumatera Utara. Pemberdayaan ekonomi kerakyatan melalui peningkatan kemampuan teknologi pelaku usaha mikro, kecil, dan menengah serta optimalisasi pembangunan desa dan sektor pertanian merupakan salah satu cara pemerintah daerah untuk menciptakan kesempatan kerja bagi angkatan kerja di masing-masing wilayah masing-masing. Helmalia \& Afrinawati (2018) menyatakan bahwa keberadaan usaha mikro, kecil, 
dan menengah berperan strategis dalam mengatasi masalah kemiskinan dan pengangguran.

Berdasarkan hasil pengolahan dengan GWL dihasilkan 33 model kemiskinan berdasarkan karakteristik masing-masing wilayah kabupaten/kota di Provinsi Sumatera Utara. Terdapat sebelas kabupaten/kota dimana seluruh variabel penjelas signifikan berpengaruh terhadap kemiskinan, yaitu Kabupaten Tapanuli Tengah, Tapanuli Utara, Dairi, Langkat, Samosir, Batubara, Labuhanbatu Selatan, Nias Utara, Nias Barat, Kota Tanjung Balai, dan Kota Padang Sidempuan.

Tabel 6: Variabel Signifikan yang Memengaruhi Kemiskinan

\begin{tabular}{|c|c|}
\hline Variabel & Kabupaten/Kota \\
\hline $\begin{array}{l}\text { Persentase rumah tang- } \\
\text { ga dengan luas lantai }< \\
8 \mathrm{~m}^{2} \text { per kapita }\end{array}$ & $\begin{array}{l}\text { Mandailing Natal, Tapanuli Tengah, Tapanuli Utara, Dairi, Langkat, } \\
\text { Samosir, Batubara, Labuhanbatu Utara, Labuhanbatu Selatan, Nias Utara, } \\
\text { Nias Barat, Tanjungbalai, Padangsidempuan, Padanglawas, Padanglawas } \\
\text { Utara, Pematangsiantar, Labuhan Batu, Simalungun, Tapanuli Selatan, } \\
\text { Tebingtinggi, Sibolga, Karo, Deli Serdang, Pakpak Bharat, Toba, Asahan, } \\
\text { Binjai, Medan }\end{array}$ \\
\hline $\begin{array}{l}\text { Persentase penduduk } \\
\text { yang menggunakan }\end{array}$ & $\begin{array}{l}\text { Mandailing Natal, Tapanuli Tengah, Tapanuli Utara, Labuhanbatu, } \\
\text { Asahan, Simalungun, Dairi, Langkat, Samosir, Batubara, Labuhanbatu }\end{array}$ \\
\hline listrik PLN & $\begin{array}{l}\text { Utara, Labuhanbatu Selatan, Nias Utara, Nias Barat, Tanjungbalai, } \\
\text { Padangsidempuan, Binjai, Medan }\end{array}$ \\
\hline $\begin{array}{l}\text { Persentase penduduk } \\
\text { yang mengalami keluh- } \\
\text { an kesehatan selama } \\
\text { sebulan terakhir }\end{array}$ & $\begin{array}{l}\text { Nias, Mandailing Natal, Tapanuli Selatan, Tapanuli Tengah, Tapanuli } \\
\text { Utara, Dairi, Langkat, Nias Selatan, Pakpak Bharat, Samosir, Batubara, } \\
\text { Labuhanbatu Selatan, Nias Utara, Nias Barat, Tanjungbalai, Tebingtinggi, } \\
\text { Padangsidempuan, Medan, Sibolga }\end{array}$ \\
\hline $\begin{array}{l}\text { Tingkat setengah pe- } \\
\text { ngangguran }\end{array}$ & $\begin{array}{l}\text { Nias, Mandailing Natal, Tapanuli Selatan, Tapanuli Tengah, } \\
\text { Tapanuli Utara, Labuhan Batu, Simalungun, Dairi, Langkat, Nias } \\
\text { Selatan, Pakpak Bharat, Samosir, Batubara, Labuhanbatu Selatan, Nias } \\
\text { Utara, Nias Barat, Tanjungbalai, Padangsidempuan, Tebingtinggi, Medan, } \\
\text { Binjai, Pematangsiantar, Gunungsitoli }\end{array}$ \\
\hline $\begin{array}{l}\text { Persentase pekerja infor- } \\
\text { mal }\end{array}$ & $\begin{array}{l}\text { Nias, Mandailing Natal, Tapanuli Selatan, Tapanuli Tengah, Tapanuli } \\
\text { Utara, Toba, Labuhan Batu, Dairi, Karo, Deli Serdang, Langkat, Ni- } \\
\text { as Selatan, Pakpak Bharat, Samosir, Batubara, Labuhanbatu Utara, } \\
\text { Labuhanbatu Selatan, Nias Utara, Nias Barat, Sibolga, Tanjungbalai, Tebi- } \\
\text { ngtinggi, Medan, Padangsidempuan, Gunungsitoli }\end{array}$ \\
\hline IPM & $\begin{array}{l}\text { Tapanuli Selatan, Tapanuli Tengah, Tapanuli Utara, Toba, Simalungun, } \\
\text { Dairi, Langkat, Samosir, Batubara, Labuhanbatu Selatan, Nias Utara, Nias } \\
\text { Barat, Tanjungbalai, Tebingtinggi, Pematangsiantar, Padangsidempuan }\end{array}$ \\
\hline TPAK & $\begin{array}{l}\text { Tapanuli Selatan, Tapanuli Tengah, Tapanuli Utara, Toba, Labuhan } \\
\text { Batu, Dairi, Langkat, Samosir, Batubara, Labuhanbatu Selatan, Nias } \\
\text { Utara, Nias Barat, Tanjungbalai, Tebingtinggi, Pematangsiantar, Medan, } \\
\text { Padangsidempuan }\end{array}$ \\
\hline
\end{tabular}

Pola penyebaran estimasi persentase penduduk miskin di Sumatera Utara dengan model GWL pada Gambar 2 mirip dengan pola Gambar 1. Pada Gambar 2 ditunjukkan bahwa estimasi persentase penduduk miskin di Sumatera Utara mendekati kondisi sebenarnya (Gambar1). Hal ini juga didukung dari nilai koefisien determinasi $\left(\mathrm{R}^{2}\right)$ sebesar 0,8593 . Koefisien determinasi menunjukkan persentase variabel respon yang dapat dijelaskan oleh variabel prediktor. Hasil pengolahan data menunjukkan bahwa 85,93 persen persentase penduduk miskin 
di Sumatera Utara dapat dijelaskan oleh seluruh variabel prediktor menggunakan model GWL. Yulita et al. (2015) menjelaskan bahwa pemodelan dengan GWL mampu meningkatkan ketepatan estimasi parameter.

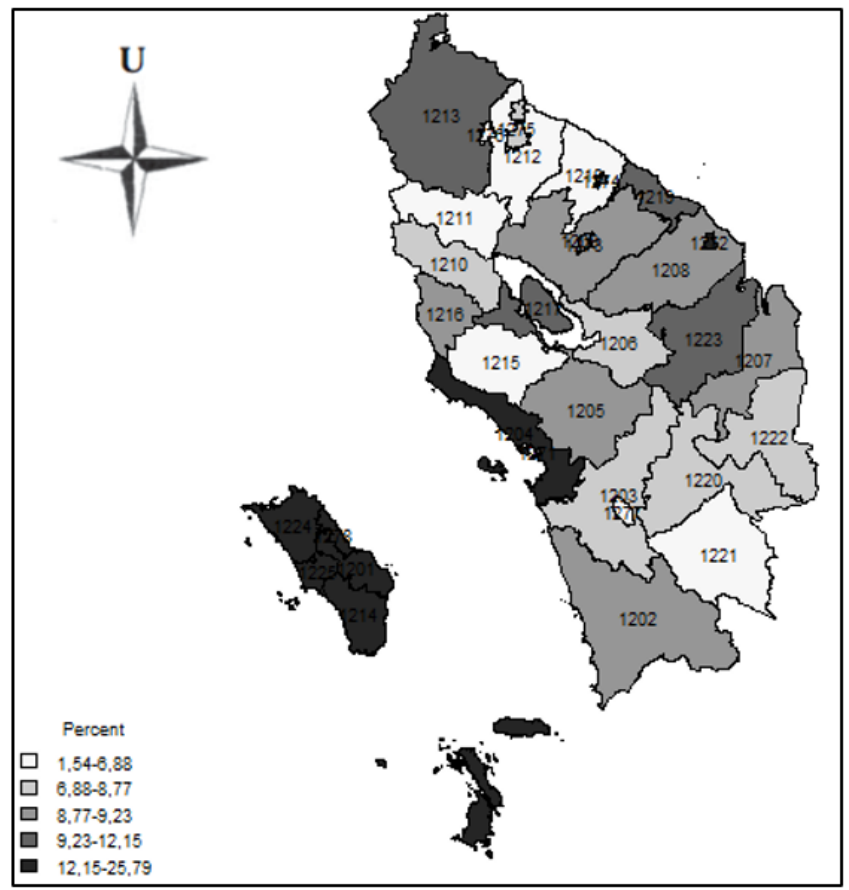

Gambar 2: Estimasi Persentase Penduduk Miskin di Sumatera Utara dengan Model GWL

\section{Simpulan dan Saran}

Penerapan metode Geographically Weighted Lasso dalam memodelkan kemiskinan di Sumatera Utara dapat mengatasi masalah heterogenitas spasial dan multikolineritas. Pemodelan tingkat kemiskinan dengan GWL memberikan hasil estimasi parameter yang berbeda-beda di tiap wilayah kabupaten/kota. Hasil penelitian menunjukkan bahwa variabel yang paling banyak berpengaruh signifikan terhadap kemiskinan di Sumatera Utara adalah persentase rumah tangga dengan luas lantai di bawah $8 \mathrm{~m}^{2}$, tingkat setengah pengangguran dan persentase pekerja informal. Hal ini menunjukkan bahwa kemiskinan di Sumatera Utara paling banyak dipengaruhi ketiga variabel tersebut sehingga perlu mendapat perhatian khusus dari pemerintah daerah dalam penyusunan program pengentasan kemiskinan. Pemodelan kemiskinan dengan metode GWL mampu meningkatkan 
ketepatan estimasi parameter sehingga program pengentasan kemiskinan di Sumatera Utara akan lebih efektif jika disesuaikan dengan karateristik masingmasing wilayah.

Koordinasi antara pemerintah daerah Provinsi Sumatera Utara dan pemerintah daerah masing-masing kabupaten/kota perlu ditingkatkan untuk program pengentasan kemiskinan. Fokus program pengentasan kemiskinan pada pembangunan infrastruktur yang dapat mendorong lajunya pertumbuhan ekonomi dan pemberdayaan ekonomi kerakyatan khususnya pelaku usaha pada sektor pertanian dan UMKM.

Penelitian ini memiliki keterbatasan waktu pengamatan hanya pada tahun tertentu sehingga fenomena kemiskinan tidak dapat dianalisis lebih mendalam. Penelitian selanjutnya dapat menggunakan periode waktu yang lebih panjang sehingga identifikasi kemiskinan dengan pendekatan spasial lebih bermakna.

\section{Daftar Pustaka}

[1] Agustina, M. F., Wasono, R., \& Darsyah, M. Y. (2015). Pemodelan Geographically Weighted Regression (GWR) pada tingkat kemiskinan di Provinsi Jawa Tengah. Jurnal Statistika Universitas Muhammadiyah Semarang, 3(2), 67-74.

[2] Anselin, L. (1988). Spatial econometrics: Methods and models. Dordrecht: Springer Netherlands.

[3] Bangun, R. H. (2020). Determinan Peningkatan Pembangunan Manusia Di Sumatera Utara. Publikauma: Jurnal Administrasi Publik Universitas Medan Area, 8(1), 32-39. doi: https://doi.org/10.31289/publika.v8i1.3066.

[4] Basorudin, M., Heryanti, R., Humairo, N., Putro, A. W., \& Firdani, A. M. (2019). Gambaran sektor ketenagakerjaan dan kemiskinan di Provinsi Bengkulu. OIKOS: Jurnal Kajian Pendidikan Ekonomi dan Ilmu Ekonomi, 3(2), 79-91. doi: https://doi.org/10.23969/oikos.v4i1.1866.

[5] BPS. (2019). Data dan informasi kemiskinan kabupaten/kota tahun 2019. Jakarta: Badan Pusat Statistik.

[6] BPS Provinsi Sumatera Utara. (2020a). Hasil survei sosial demografi dampak COVID-19 Provinsi Sumatera Utara 2020. Medan: Badan Pusat Statistik Provinsi Sumatera Utara.

[7] BPS Provinsi Sumatera Utara. (2020b). Profil kemiskinan di Sumatera Utara Maret 2020. Medan: Badan Pusat Statistik Provinsi Sumatera Utara.

[8] BPS Provinsi Sumatera Utara. (2020c). Provinsi Sumatera Utara dalam angka 2020. Medan: Badan Pusat Statistik Provinsi Sumatera Utara.

[9] Damayanti, Y., \& Ratnasari, V. (2013). Pemodelan penduduk miskin di Jawa Timur menggunakan Metode Geographically Weighted Regression (GWR). Jurnal Sains dan Seni POMITS, 2(2), 329-334.

[10] Dariwardani, N. M. I. (2014). Analisis dinamika kemiskinan (poverty dynamics) di Bali berdasarkan data Susenas Panel 2008-2010. Jurnal Ekonomi Kuantitatif Terapan, 7(1), 7-15. doi: https:/ / doi.org/10.24843/JEKT.2014.v07.i01.p02.

[11] Efron, B., Hastie, T., Johnstone, I., \& Tibshirani, R. (2004). Least angle regression. The Annals of Statistics, 32(2), 407-499.

[12] Fotheringham, A. S., Brunsdon, C., \& Charlton, M. (2002). Geographically weighted regression: The analysis of spatially varying relationships. John Wiley \& Sons. 
[13] Gujarati, D. N., \& Porter, D. C. (2009). Basic econometric (5th edition). New York: McGraw Hill.

[14] Helmalia, H., \& AfrinawatI, A. (2018). Pengaruh e-commerce terhadap peningkatan pendapatan usaha mikro kecil dan menengah di Kota Padang. JEBI (Jurnal Ekonomi dan Bisnis Islam), 3(2), 237-246. doi: https://doi.org/10.15548/jebi.v3i2.182.

[15] Kusuma, G. W., \& Wulansari, I. Y. (2020). Analisis kemiskinan dan kerentanan kemiskinan dengan regresi ridge, lasso, dan elastic-net di Provinsi Jawa Tengah tahun 2017. Prosiding Seminar Nasional Official Statistics 2019, 503-513. doi: https://doi.org/10.34123/semnasoffstat.v2019i1.189.

[16] Maggri, I., \& Ispriyanti, D. (2013). Pemodelan data kemiskinan di Provinsi Sumatera Barat dengan metode Geographically Weighted Regression (GWR). Media Statistika, 6(1), 37-49. doi: 10.14710/medstat.6.1.37-49.

[17] Puspita, D. W. (2015). Analisis determinan kemiskinan di Provinsi Jawa Tengah. JEJAK: Jurnal Ekonomi dan Kebijakan, 8(1), 100-107. doi: https://doi.org/10.15294/jejak.v8i1.3858.

[18] Saputro, A. E. S., \& Utomo, A. P. (2010). Faktor-faktor yang mempengaruhi kemiskinan secara makro di lima belas provinsi tahun 2007. Jurnal Organisasi dan Manajemen, 6(2), 89-100.

[19] Septiyanto, W. G., \& Tusianti, E. (2020). Analisis spasial tingkat pengangguran terbuka di Provinsi Jawa Barat. Jurnal Ekonomi Indonesia, 9(2), 119-131.

[20] Setiyorini, A., Suprijadi, J., \& Handoko, B. (2017). Implementations of geographically weighted lasso in spatial data with multicollinearity (Case study: Poverty modeling of Java Island). AIP Conference Proceedings, 1827(1), 020003. doi: https://doi.org/10.1063/1.4979419.

[21] Sisca HS, V., Hamzah, A., \& Syechalad, M. N. (2013). Pengaruh kesempatan kerja, pendidikan dan kesehatan terhadap kemiskinan di Provinsi Aceh. Jurnal Magister Ilmu Ekonomi: Pascasarjana Unsyiah, 1(4), 21-30.

[22] Sutopo, Y. K., \& Ardianti, R. R. R. (2014). Analisa pengelolaan sumber daya manusia sektor formal dan sektor informal di Jawa Timur. Agora, 2(1), 330-342.

[23] Tambun, J. M. S., \& Herawaty, R. (2018). Pemodelan faktor-faktor yang mempengaruhi indeks kedalaman kemiskinan dan indeks keparahan kemiskinan kabupaten/kota di Sumatera Utara menggunakan regresi data panel. Publikauma: Jurnal Administrasi Publik Universitas Medan Area, 6(1), 100-110. doi: https://doi.org/10.31289/publika.v6i1.1574.

[24] Taufiq, N. (2017). Pengaruh dinamika sektor pekerjaan terhadap dinamika kemiskinan di Indonesia. Sosio Konsepsia: Jurnal Penelitian dan Pengembangan Kesejahteraan Sosial, 7(1), 1-14. doi: 10.33007/ska.v7i1.1148.

[25] Wang, J., \& Zuo, R. (2020). Assessing geochemical anomalies using geographically weighted lasso. Applied Geochemistry, 119, 104668. doi: https://doi.org/10.1016/j.apgeochem.2020.104668.

[26] Wheeler, D. C. (2007). Diagnostic tools and a remedial method for collinearity in geographically weighted regression. Environment and Planning A, 39(10), 2464-2481. doi: https://doi.org/10.1068/a38325.

[27] Wheeler, D. C. (2009). Simultaneous coefficient penalization and model selection in geographically weighted regression: The geographically weighted lasso. Environment and Planning A, 41(3), 722-742. doi: https://doi.org/10.1068/a40256.

[28] Wulandari. (2018). Geographically weighted logistic regression dengan fungsi Kernel fixed gaussian pada kemiskinan Jawa Tengah. Indonesian Journal of Statistics and Its 
Applications, 2(2), 101-112. doi: https://doi.org/10.29244/ijsa.v2i2.189.

[29] Yandri, P., \& Juanda, B. (2018). Memahami Karakter kemiskinan perkotaan dengan pendekatan observasional. Jurnal Ekonomi \& Studi Pembangunan, 19(1), 75-84. doi: https://doi.org/10.18196/jesp.19.1.4276.

[30] Yuliana, \& Saputro, D. R. S. (2017). Algoritme least angle regression untuk model geographically weighted least absolute shrinkage and selection operator. Paper presented at Seminar Matematika dan Pendidikan Matematika UNY, pp. 139-144, Yogyakarta, November 11, 2017.

[31] Yulita, T., Saefuddin, A., \& Wigena, A. H. (2015). Ridge and lasso performance in spatial data with heterogeneity and multicollinearity. Forum Statistika dan Komputasi, 20(2), 96-104. 